\title{
IMPLICATIONS OF COMMODIFIED PARWA SHADOW PUPPET PERFORMANCE FOR TOURISM IN UBUD, BALI.
}

\author{
Gede Yoga Kharisma Pradana. \\ International Bali Institute of Tourism \\ yoga@stpbi.ac.id
}

\begin{abstract}
The purpose of this article was to examine the phenomenon of Balinese shadow puppet performances as a tourism entertainment spectacle in Ubud, Bali. Basically, the Parwa shadow puppet shows as Balinese shadow puppets were stag for the purposes of traditional ceremonies for a long duration. In contrast, the type of Parwa shadow puppet shows in Ubud for tourism were stag with a shorter duration. This phenomenon certainly raised a big question about the implications of stag such performances for tourism. This article used qualitative research methods. All data were obtained through literature study, interview and observation. After all data were obtained, they were analyzed by using the perspective of cultural studies. The results showed that the commodification of Parwa shadow puppet shows for tourism had economic, social and cultural implications. Economically, the commodification of the Parwa shadow puppet show for tourism had implications for a change in instrumental value, adding profit to cottage owners and retailers. Socially, the commodity had implications in the popularity as well as the identity of shadows puppet group. Culturally it had implications for the preservation of cultural identity in the context of tourism, mediation of cultural promotion to tourists, cultural degradation of puppets and the difficulty of enculturation.
\end{abstract}

Keywords: Implications, Commodified, Parwa Shadow Puppet Performances, Tourism, Ubud.

\section{I.Introduction}

Parwa is a traditional Balinese shadow puppet performed for the purposes of traditional ceremonies (Mangkunagara, 1957; Simmer, 1975; Phillpot and Mc Neil, 1968). Parwa shadow puppet performances stag by using a large narrative of Mahabrata play accompanied by gamelan accompaniment four gender with long duration performances only on certain days in the context of traditional ceremonies. The weight of the show is strongly influenced by the existence of a play that contains a meaningful story of civil war against on Pandawa and Kurawa in upholding justice. In contrast to the literary play, the commodification form of Parwa shadows puppet for tourism in Ubud using carangan plays with a shorter duration.

The carangan as mini-story is a development of the epic Mahabrata. In contrast to the main play on the pates shadow puppet for the ceremony, the carangan play on the commodification form of the pates shadow puppet show does not tell about the victory of the Pandawa against the Kurawa in a big family 
conflict, but the Pandawa victory against the monster group. In particular, the series of stories show the puppeteer's desire to voice the familiar aspect in the dimensions of Balinese cultural wisdom of tourists.

The kinship value of this regard is not only considered a role model in show of the performing arts, but has become a power of Balinese cultural wisdom, especially in fostering and maintaining the kinship system as the basis of social power across generations. In addition, the victory of the Pandawa, Bima in the narration of the show plays laden with nuances of sacrifice that seeks to remind tourists that in the process of building relationships to loved ones not be spared from the sacrifice of time, material and energy. Therefore, the entertainment spectacle as in the form of Parwa shadows puppet commodification for tourism certainly gives its own specific attraction during the holidays in Ubud.

The substance of carangan story existence plays has improved an appearance of the commodification Parwa shadow puppet shows for tourism in Ubud. As Parwa shadow puppet shows to take the play as mediation in conveying message to the audience, Parwa shadows puppet performance also requires the presence of performance structure, musical accompaniment, shadow puppet, sound system, lamp, screen and stage. The subject is synonymous with the appearance of the commodity structure form of Parwa shadow puppet show for tourism in Ubud which consists of pamungkah, peguneman, nyerita, angkat-angkatan, rebong, bapang delem and pesiat. Pamungkah, peguneman, nyerita, angkat-angkatan, rebong, bapang delem and pesiat are the stages of traditional shadow puppet show structure in Bali (Holt and Bateson, 1970; Curell , 1980 ; Champlin, 1980).

Structurally, the stage of Parwa shadows puppet shape of tourism in Ubud consists of pategak stages, marked as the beginning of the show by opening getting activities in order to choose wayang for the performance. The stages of pamungkah, marked the readiness of the puppeteer in kayonan dancing. Kayonan danced, moved to the right, left and finally plugged in the middle of the screen (Holt and Bateson, 1970). At that time, kayonan serves as a limiting wayang protagonist and wayang antagonist. The stage is then followed by a jejer or member wayang that is the puppeteer choosing and sticking the protagonist of wayang on the right and the wayang antagonistic to the left of kayonan (Mangkunagara, 1957; Hobart, 1987). The figures plugged to the right include the figures of Bhiksakarma, Kunti and Bima. While the shadow puppets plugged into the left of the kayonan are Detya Baka and the monsters. When all the puppet characters have been plugged in, a guide appears in front of the screen giving a general picture of the shadow puppet. The stages of the pamungkah to a sway of kayonan by the puppeteer.

Peguneman is the next stage as a sign of the release puppet characters that will conduct the trial (Mangkunagara, 1957; Holt and Bateson, 1970). The characters are Bhiksakarma, Kunti, Bima and the advisor of the main protagonist characters as Tualen and Merdah with the accompaniment of arum forest song. Before the end of the arum forest song, the mastermind could utter a mantra. With the end of arum forest song indicates that it has entered the stage of nyerita (Sedana, 2002). The pain involves a dialogue of peguneman among the protagonists, Bhiksakarma, Dewi Kunti and Bima.

The angkat-angkatan phase is the stage of departure from wayang figures of the battlefield (Mangkunagara, 1957; Hobart, 1987; Harford, 1957). At angkatangkatan, wayang characters like Bima are going to the place where the monsters 
party is held. As long as the protagonist who is traveling has not reached the destination at that stage is called to rebong (Mangkunagara , 1957 , Beaument, 1938; Inverarity, 1938). The tadpole marked the mood of the destination where there was a woman who was handing over tax to Detya Baka, the king of monsters that were having fun. To reinforce the atmosphere of excitement of Detya Baka, the puppeteer adds the Bondres scene, Luh-Muani puppets. After the excitement of Detya Baka passed is the stage of Bapang Delem. Bapang Delem tells Delem and Sangut as the faithful servants of the main antagonist (Mangkunagara, 1957; Zurbuchen, 1987). The accompanying song named Bapang Delem also enlivened the stage until the arrival of a monster group to await the offerings from Bhiksakarma. Finally, there is a big battle between the Bhiksakarma with the support of the Pandawa against the monster group belonging to the pest stage. The end of the story is told that the king of the monsters has been defeated by Bima.

The whole series of show stories became livelier thanks to the strains of the accompaniment of four gender along with the sound system with a magnificent stage setting. In addition, the puppeteer has successfully proved to management stage of tourism destination that they are able to compete for presenting a new and quality entertainment offerings in the context of Bali tourism show in Ubud.

The article entitled Implications of commodification Parwa shadow puppet performance for Tourism in Ubud conducted to understand the extent contribution to existence of the commodification form shadow puppet show. The phenomenon is interesting to be studied critically in the midst of a variety of tourism entertainments in Ubud-Bali, where the show is able to become one of the favorites.

\section{Research Methods}

The research method used in the study of Parwa shadows puppet phenomenon for tourism in Ubud was qualitative research method. The writing of the article was based on observation, interview and literature study. Primary data was obtained directly from the field using observation and interview techniques (Glenn, 2010; Walliman, 2011). Stages of observation conducted before and after the interview for the informants. While the interview was done after meeting with the puppeteer, the informant was determined purposively. Based on the data provided by the informant was still less to reveal about the problem, so at that time done snowball sampling. The stages succeeded in obtaining important data into other informants, especially data into the magnitude of contributions to the commodification of Parwa shadow puppet show for tourism in Ubud. For completeness of the analysis, before and after the study library studies was conducted to establish the desire and results of study completed in the form of articles. The result of the study of leprosy was a useful secondary data into the elaboration of scientific data (De Miller, 2000; Walliman, 2011). All the data that had been collected was then followed by an analysis using the theory of deconstruction and practical theory to derive conclusions.

\section{Findings}

Implications from the form of commodification Parwa shadow puppet show for tourism in Ubud. This section explores the contribution effects of the existence of the commodity form of the Parwa shadow puppet show for tourism in Ubud. The 
commodity of Parwa shadow puppet shows for tourism in Ubud has economic, cultural and social implications.

\subsection{Economic Implications}

The commodification form of Parwa shadow puppet shows for tourism in Ubud had economic implications for the perpetrators. The creation, commodification Parwa shadow puppet show for tourism could not be separated from the economic boost of tourism opportunities that have generated profit for the perpetrators. Along with that, the social relationships between the preparation of the show have changed more from the professional relationship with more accurate measurements based on nominal money. Thus the dominance of the humanitarian value of the show is more transformed into an economic value which means the official commercial exchange rate on the form of commodification Parwa shadow puppet shows for tourism in Ubud.

As a commodity, the form of commodification Parwa shadow puppet shows for tourism in Ubud seemed to have been packaged in accordance with the tastes of tourists. It is synonymous with a marketed product is for profit (Ardono, 1979: 123). Of course, the profits earned in the show were from the sale of ticket priced up to Rp. 50,000 per-person. On the profit sharing adjusted to the money earned from the results of each stage. As affirmed by a hirer and owner of a cottage in Ubud on 12 August 2015 is as follows :

'...this show is business, we sell, if the tourist a lot of watching, we get lots of parts and if a little audience, we can little part. Although, the results obtained each stag is not certain, but the most certain thing from the state of the audience is the season quiet and busy season. In the lonely season, masterminds can earn 50,000 once performances and 25,000 for 4 people each as a gender and 2 people of tututan or servant of puppeteer. When the peak season, the puppeteer earns 150,000 and each 75,000 for 4 people and 2 people for a one-time of tututan. When averaged earnings in each stag can reach 100,000 for the mastermind and 50,000 for each of its members".

The above statement shows that the commodification of Parwa shadow puppet shows in the context of tourism in Ubud has provided economic benefits of the perpetrators. In addition, the presence of regular performances in Ubud had an impact on increasing revenues from surrounding communities that were trying their luck as retail merchants around the venue. Therefore, the presence of the commodity form of Parwa shadow puppet shows for tourism in Ubud was not only important to the tourism actors in Ubud but also became something important for small traders in getting income from consumers. Although the income from the Parwa shadow puppet show performed in Ubud was non-permanent, it's existence is very helpful in easing the economic burden in the family. As Sumandhi confirms a trader on November 1, 2015 :

".....this shadow puppet show is very encouraging. Although the amount is not fixed, it really helps the condition of our kitchen".

Based on the narrative from informants it can be understood that existence of the form of commodification Parwa shadow puppet shows was not only to contribute economic to the perpetrators but also the economic implications for families of 
traders that were pitting fortunes around the place of stag. This indicates that the form of commodification Parwa shadow puppet shows had been useful in reviving the wheels of the economy of Ubud. The statement was in line with the opinion of a Puri Ubud figure named Cokorda Raka Suastika on 10 August 2015 : .

"............this shadow puppet shows turned out to have provided employment opportunities apart from the main work that is occupied by both the Ubud people and the people outside Ubud. Starting from the merchant until the printing press earns additional income. The driver of the tour package to the cottage tours did not miss getting paid more as a service during the way there".

From the above informant statement shows that the form of commodification Parwa puppet shows for Ubud tourism contribution not only felt by tourists and the perpetrators but that it is true implicated in the economic wheel in Ubud.

\subsection{Cultural Implications}

Commodification of Parwa shadow puppet shows for Ubud tourism besides giving opportunity for puppeteer from stag a type of Balinese shadow puppet and performing duties as a spokesman, the moment of the show has become the arena for cultural promotion. Therefore, the form of commodification Parwa shadow puppet shows for tourism in Ubud can be said to have cultural implications especially in puppet culture. On the one hand, the commodification of the Parwa shadow puppet show for tourism in Ubud turns out to be a cultural promotion media for the tourists that come to Ubud.

A variety of tourism performing arts can improve the image of Indonesia in the international world as well as provide an image of the tourists about the potential for cultural attractions in Bali (Ruastiti, 2015). On that occasion, the commodification of the Parwa shadow puppet show for tourism in Ubud has promoted shadow puppet as a manifestation of Balinese culture, Ubud as a tourist destination to puppeteer as a performing artist. Based on that, Ubud is also increasingly known as a tourist destination in Bali thanks to a number of puppet dialogs that can be listened as follows :

Merdah: come on, father !.

Tualen: well. Hehehe, helo helo welcome to Bali and Ubud Bali, watching in Ubud Bali.

Based on the above dialogue it could be seen that the commodification of Parwa puppet shows for tourism in Ubud had participated to promote Ubud as one of the tourist destinations in Bali. Cultural promotion was also done by the guides that explained Ubud and Parwa shadow puppet even the puppeteer completed with his expertise in making puppets, Balinese dancing and sculpt wooden statues. The response from tourists in watching the form of commodification Parwa shadow puppet shows for tourism until the end also showed a good appreciation to the promotion of culture in the shadow puppet performance. From the dimension of communication it could be said that the form of commodification Parwa shadow puppet shows could be an international communication media. Gill (1993) says International communication is a communication that involves the interaction 
process and its scope is cross-country and takes place among people of different nationalities.

Revisiting that the commodification of Parwa shadow puppet shows for tourism in Ubud always seemed to be crowded around tourists as it can be said that the form of commodification Parwa shadow puppet shows for tourism in Ubud has the function of international communication. This means that there has been an expansion of cultural transmission power from oral tradition in Parwa shadow puppet show in the realm of ceremony coupled with the tourism sphere. Culturally, however, the commodification had implications for the degradation of the shadow puppet culture.

Cultural degradation can be understood as cultural marginalization along with a drastic decline in quality of cultural values (Wiliams, 1980). The degradation of the puppet culture in the commodification of Parwa shadow puppet shows for tourism in Ubud is a culturally negative implication. In total, the Parwa shadow puppet show which is stag in the context of the ceremony involves a series of preparations and execution is complex. Almost at every stage the circuit has a magical meaning which overall reinforces the spiritual vibrations in the sacred ceremony at the temple. In contrast to the commodification of the Parwa shadow puppet show for tourism has lost its sanctity as the modification some of the components the show becomes much more practical, it appears more laborintensive, more ergonomic and more commercial as a commodity offered to tourists.

The secularization of the Parwa shadow puppet show for Ubud tourism has removed the important religious ceremonies and the sanctity of the place as part in the show offerings. The orientation of non-formal education to humanitarian formation has further shifted to the dominance of profit-oriented has greatly altered the familiarity, the appearance of serious shadow puppet performances for the Balinese people into more mysterious and enchanting show for tourists.

The context of the show is intended for the tourists, so the means of upakara are used as necessary and as simple as possible only as an artificial commodity not as a means of more value for the strength of the wholeness of the community when it is held at a sacred traditional ceremony. The cultural capital of the commodification of Parwa shadow puppet shows for Ubud tourism that has been converted into economic capital for the perpetrators is more symbolic than social. In other words, the commodification of the Parwa shadow puppet show for tourism in Ubud is based on entertainment rather than a total theater of multifunctional, ethnic, religious, and racial values. Cultural deposits that have been given are more difficult to develop than in the audience of traditional Balinese shadows puppet performances in the context of traditional ceremonies.

The uniqueness of more performances into the uniqueness of an attraction often leaves a mystery as their cultural background is much different (Victoria, 1985). Of course, positively the dimension of mystery for them could invite a desire to watch again and even learn more. However, the puppeteer's struggle for the preservation of the puppet culture, including the mission of puppeteer regeneration is far more difficult than in the context of the religious ceremony. Because they come to the show more as a protected free connoisseur rather than as an event participant bound by cultural heritage genealogy. Thus cultural enculturation in that 
context actually takes a longer time and be more difficult to see the potential differences in their cultural background.

The phenomenon of Parwa shadow puppet shows for tourism in Ubud is a form of responders ' to response global opportunities from tourism in Ubud. Related to that, there has been a change in the form of Balinese shadow puppet show into a commodity that can be consumed by anyone. Correspondingly, Mc Kean in Pichard (1996) says that there are symptoms of Balinese who want to be modern while preserving their cultural traditions. In effect, relative degradation is inevitably linked to the wishes of tourism actors in winning the market among various tourism performances in Ubud. Cultural degradation here is a siltation of the shadow puppet culture. On the other hand, many tourists are interested come to Ubud because of the unique aspects of culture.

Throughout the stag of the commodification of Parwa shadow puppet show for tourism in Ubud, the most actors felt benefited from the arrival of tourists. Not a few are encouraged to preserve the culture and conduct sekaa in the context of tourism. In that case, the form of commodification of shadow puppet performances for tourism in Ubud has stimulated local people to strengthen the characteristic by digging back the form of a culture that is almost extinct to be developed as a tourism commodity. This phenomenon leads to the preservation of cultural identity in the realm of tourism. Preservation type of cultural identity would have an impact on the emergence desire for tourists to explore and enjoy a variety of Balinese arts dishes that has its own trademark. Similarly, the form of commodification of Parwa shadow puppet shows for tourism in Ubud, although it's different from the point of view of the totality of traditional Parwa shadow puppet show that seems to be a show that tourists are looking for because it still has its own characteristics.

\subsection{Social Implications}

Performance of commodity shapes Parwa shadow puppet shows for tourism in Ubud had social implications. The function of each element in a structure was intended to meet the needs (Stocking, 1995). As the biological, psychological and sociocultural prerequisites of the implementation of a shadow puppet show as collective work still have an integrated function of the sustainable of the Parwa shadow puppet show in Ubud.

In such circumstances, the puppeteer has an opportunity to develop the performance creativity as a modern artist much appreciated his creativity. As a traditional shadow puppet show, collective values are still maintained (Marjorie, 1948 ; Bohmer, 1971 ; Bussel, 1955 ; Zurbuchen, 1987 ; Champlin, 1980). The creativity of the puppeteer in commodifying the Parwa shadow puppet show has given a new variant of the art of tourism performances in Ubud.

In the form of commodification of Parwa shadow puppet show for tourism in Ubud, the aesthetic totality of the show was a major factor of the audience appearance that will be missed on that day. In line with that, Shohat and Stam in Smiers (2003) argued that art can be a symbolic battleground because it can take care, increase or change the awareness of the audience. In that connection, the form of commodification of the Parwa shadow puppet show can still function as a builder and confirmation of the art group identity. Therefore, the form of commodification 
Parwa shadow puppet shows is understood part of social struggle for Parwa shadow puppet performance group of the expression of beauty that is distributed to the tourists as the audience to participate in maintaining and supporting even loving the arts of Bali. In that context, although not many sets of cultural values still play a role in reviving symbolic expressions, the commodification of the Parwa shadows puppet performances can be a spectacular spectacle. Transmission of cultural values of the commodification of Parwa shadow puppet plays for subsequent tourism internally will strengthen the social relations of the perpetrators. As to contribute back to the awareness of the mastermind as the artistic responsible. Second, the succession of the mastermind as an artist in the middle of the audience. Third, the increasing popularity of shadow puppet shows group of Ubud, Bali.

\section{Conclusions}

Based on the study of the phenomenon of Parwa shadow puppet show for tourism in Ubud, it can be concluded that form commodification of Parwa shadow puppet shows for tourism in Ubud had implicated economically, socially and culturally. Economically, the form of commodification Parwa shadow puppet shows for tourism had implications to changes in instrumental value, increased profit for cottage owners and retail traders. Socially, the commodification of Parwa shadow puppet shows for tourism in Ubud had already implicated in formation of popularity as well as the identity of shadow puppet group. Culturally, the form of commodification Parwa shadow puppet shows for tourism in Ubud had implications to the preservation of cultural identity in the realm of tourism, mediating cultural promotion to tourists but resulting in the dedication of puppet culture and the difficulties of inculturation of shadow puppet culture.

\section{BIBLIOGRAPHY}

Ardono, Theodor. 1979. Dialectic Of Enlightment. London : Verso.

Beaument, Cyril. 1938. Puppets and Puppet Stage. London : The Studio.

Bohmer, G. 1971. The Wonderfull World Of Puppetery. London : Macdonald

Bussell, J. 1955. The Puppet Theatre. London : Faber and Faber.

Champlin, C. 1980. Puppetery and Creative Dramatics in Story Telling (ed. Ann Schawalb). London : Renfro Studio. 
Curell, D. 1980. The Complete Book Of Puppet Theatre. London : A and C Black Publishers.

De Miller, Anna L. 2000. Linguistics: A Guide To The Reference Literature. Colo : Libraries Unlimited.

Gill, Stephen, ed. 1993. Gramsci, Historical Materialism and International Relations. Cambridge, U.K: Cambridge University Press.

Glenn, Jerome Clayton. 2010. Handbook Of Research Methods. India : Oxford Book.

Harford, R.T.E. 1976. The Complete Book Of Puppets and Pupeteering. New York : Drake.

Hobart, angela. 1987. Dancing Shadow Of Bali. London : KPI Ltd.

Holt, C. and Bateson, G. 1970. Traditional Balinese Culture. New York : Columbia University Press.

Inverarity, R.B. 1938. A Manual Of Puppetery. London : Binfords \& Mort.

Mangkunagara VII. 1957. On The Wayang Kulit, Purwa, and It's Symbolic and Mystical Elements. New York : Cornell University Press.

Marjorie, Batchelder. 1948. The Puppet Theatre Handbook. London : Faber dan Faber.

Philpott, A.R. and Mc Neil , M.J. 1968. The Knowhow Book of Puppets. London : Usborne.

Pichard, Michel. 1996. Bali : Cultural Tourism and Touristic Culture. Singapore : Archipelago.

Ruastiti, Made. 2015. Balinese Tourist Performing Art in Perspective Of Cultural Studies. Yogyakarta : Kanisius.

Sedana, I Nyoman. 2002. Kawi Dalang : Creativity in Wayang Theatre, A Dissertation Submittid to the Graduate Faculty of The University Of Gerogia in Partial Fullfilment of Requirements for the Degree. Gerogia : Athens.

Simmer, R. 1975. The World Of Puppets. London : Crowell Inc.

Smiers, Joost. 2003. Art Under Pressure: Promoting Cultural Diversity In The Age Of Globalization. London and New York : Zed Books. 
Stocking, George W., Jr. 1995. From Fieldwork To Functionalism: Malinowski and The Emergence Of British Social Anthropology. In After Taylor: British Social Anthropology 1888-1951. Madison : Univ. of Wisconsin Press.

Victoria, Clara Van Groenendael. 1985. The Dalang Behind The Wayang. The Role Of The Surakarta and The Yogyakarta Dalan in IndonesianJavanise Society. Dordretch, Cinnaminson : Foris. Verhandelingen Van Het Koninklijk Instituut voor Taal-, Land-en Volkerkunde 114.

Walliman, Nicholas. 2011. Research Methods: The Basics. New York : Routledge.

Wiliams, Raymond. 1980. Problems in Materialism and Cultural. London : Verso.Zurbuchen,

Mary, Sabrina. 1987. The Language of Balinese Shadow Theatre. Princeton : Princeton University Press. 